\title{
1. Rare Neutral Diphosphine Complexes of Scandium(III) and 2Yttrium(III) Halides
}

\author{
s Marina Carravetta, Maria Concistre, William Levason, Gillian Reid,*() and Wenjian Zhang \\ 4 School of Chemistry, University of Southampton, Highfield, Southampton SO17 1BJ, U.K. \\ 5 S Supporting Information
}

\begin{abstract}
6 ABSTRACT: Reaction of $\mathrm{Me}_{2} \mathrm{PCH}_{2} \mathrm{CH}_{2} \mathrm{PMe}_{2}$ or $o-\mathrm{C}_{6} \mathrm{H}_{4}\left(\mathrm{PMe}_{2}\right)_{2}$ $(\mathrm{L}-\mathrm{L})$ with a suspension of $\mathrm{ScI}_{3}$ or $\mathrm{YI}_{3}$ in $\mathrm{MeCN}$ solution under rigorously anhydrous and oxygen-free conditions produced the highly unusual complexes $\left[\mathrm{ScI}_{3}(\mathrm{~L}-\mathrm{L})_{2}\right],\left[\mathrm{YI}_{3}\left(\mathrm{Me}_{2} \mathrm{PCH}_{2} \mathrm{CH}_{2} \mathrm{PMe}_{2}\right)_{2}\right]$, and $\left[\mathrm{YI}_{3}\left\{o-\mathrm{C}_{6} \mathrm{H}_{4}\left(\mathrm{PMe}_{2}\right)_{2}\right\}_{2} \mathrm{MeCN}\right]$. X-ray crystal structures reveal that the scandium complexes adopt seven-coordinate, pentagonal-bipyramidal geometries with chelating diphosphines, while the eight-coordinate $\left[\mathrm{YI}_{3}\left\{o-\mathrm{C}_{6} \mathrm{H}_{4}\left(\mathrm{PMe}_{2}\right)_{2}\right\}_{2} \mathrm{MeCN}\right]$ is dodecahedral. The complexes were characterized by microanalysis and IR and multinuclear NMR spectroscopy. Solid-state NMR data $\left({ }^{45} \mathrm{Sc},{ }^{89} \mathrm{Y},{ }^{31} \mathrm{P}\right)$ and variabletemperature solution NMR data $\left({ }^{1} \mathrm{H},{ }^{31} \mathrm{P}\left\{{ }^{1} \mathrm{H}\right\},{ }^{45} \mathrm{Sc}\right)$ are presented and compared, leading to the conclusion that the same species are present in both the solid state and $\mathrm{CH}_{2} \mathrm{Cl}_{2}$ solution. Attempts to prepare complexes with other scandium halides and with aryl diphosphines and $o-\mathrm{C}_{6} \mathrm{H}_{4}\left(\mathrm{AsMe}_{2}\right)_{2}$ are briefly described.
\end{abstract}

\section{INTRODUCTION}

20 Neutral phosphine ligands have played a key role in the 21 development of mid- and late-transition-metal coordination and 22 organometallic chemistry for the last 80 years or so. ${ }^{1}$ More 23 recent work has shown that most p-block metals and metalloids 24 also form phosphine complexes, and there are examples with 25 nonmetal halides, including those of boron, silicon, and 26 arsenic. $^{2}$ As phosphines are soft $\sigma$-donor ligands, their ability 27 to complex with the hard, oxophilic metal ions of groups 1-3 28 or the lanthanides is expected to be small. Structurally 29 authenticated complexes are limited to a very small number 30 of examples: $\left[\mathrm{BeCl}_{2}\left(\kappa^{1}-\mathrm{Ph}_{2} \mathrm{PCH}_{2} \mathrm{PPh}_{2}\right)_{2}\right]^{3 \mathrm{a}}$ and $\left[\mathrm{Be}_{2} \mathrm{Cl}_{2}(\mu\right.$ $\left.\left.{ }_{31} \mathrm{Cl}\right)_{2}\left(\mathrm{PCy}_{3}\right)_{2}\right]^{3 \mathrm{~b}}$ and our recently reported homoleptic diphos32 phine cations of lithium and sodium, $\left[\mathrm{Li}(\mathrm{L}-\mathrm{L})_{3}\right][\mathrm{Al}\{\mathrm{OC}-$ $\left.\left.33\left(\mathrm{CF}_{3}\right)_{3}\right\}_{4}\right]$ and $\left[\mathrm{Na}(\mathrm{L}-\mathrm{L})_{3}\right]\left[\mathrm{B}\left\{3,5-\mathrm{C}_{6} \mathrm{H}_{3}\left(\mathrm{CF}_{3}\right)_{2}\right\}_{4}\right](\mathrm{L}-\mathrm{L}=$ $\left.34 \mathrm{Me}_{2} \mathrm{PCH}_{2} \mathrm{CH}_{2} \mathrm{PMe}_{2}, o-\mathrm{C}_{6} \mathrm{H}_{4}\left(\mathrm{PMe}_{2}\right)_{2}\right)$. ${ }^{4}$ The only report of 35 complexes with scandium halides is of $\left[\mathrm{ScCl}_{3}\right.$ $\left.36\left(\mathrm{Ph}_{2} \mathrm{PCH}_{2} \mathrm{CH}_{2} \mathrm{PPh}_{2}\right)\right]$ and $\left[\mathrm{Sc}_{2} \mathrm{Br}_{6}\left(\mathrm{Ph}_{2} \mathrm{PCH}_{2} \mathrm{CH}_{2} \mathrm{PPh}_{2}\right)_{3}\right]$, 37 characterized only by microanalysis and IR spectroscopy, 38 and there are no reports of phosphine complexes of yttrium 39 halides. The organometallic complexes $\left[\left\{\left(\eta^{5}-\mathrm{C}_{5} \mathrm{Me}_{4}\right) \mathrm{SiMe}_{2}\left(\eta^{1}-\right.\right.\right.$ $\left.\left.\left.40 \mathrm{NCMe}_{3}\right)\right\}\left(\mathrm{PMe}_{3}\right) \mathrm{Sc}\left(\mu_{2}-\mathrm{H}\right)\right]_{2}$ and $\left\{\left(\mathrm{CH}_{3}\right)_{2} \mathrm{Si}\left[\left(t-\mathrm{C}_{4} \mathrm{H}_{9}\right)-\right.\right.$ $\left.\left.{ }_{41} \mathrm{C}_{5} \mathrm{H}_{3}\right]_{2} \mathrm{Sc}\left(\mathrm{PMe}_{3}\right)\right\}_{2}(\mu-\mathrm{Te}) \cdot \mathrm{C}_{6} \mathrm{H}_{6}$ represent extremely rare ex42 amples of neutral phosphine coordination to scandium. ${ }^{6}$ The ${ }_{43} \mathrm{Ce}(\mathrm{III})$ complex $\left[\mathrm{Ce}\left(\mathrm{MeC}_{5} \mathrm{H}_{4}\right)_{3}\left(\mathrm{PMe}_{3}\right)\right]$, obtained by reaction 44 of the thf adduct with $\mathrm{PMe}_{3}$ in diethyl ether, has been 45 structurally characterized. ${ }^{6 \mathrm{~d}}$

46 Neutral phosphino groups coordinated to Sc or $\mathrm{Y}$ are present 47 in complexes containing anionic PNP ligands, including $48\left\{\mathrm{~N}\left(\mathrm{SiMe}_{2} \mathrm{CH}_{2} \mathrm{P}^{\mathrm{i}} \mathrm{Pr}_{2}\right)_{2}\right\}^{-}$, \{pyrrole-2,5- $\left.\left(\mathrm{CH}_{2} \mathrm{PCy}_{2}\right)_{2}\right\}^{-}$, and $\{$bis49 (2-diisopropylphosphino-4-tolylamide $\}^{-}$as well as related $50 \mathrm{P}_{2} \mathrm{~N}_{2}$-donor dianionic macrocycles, ${ }^{7}$ and in complexes bearing pendant phosphino groups on a $\mathrm{Cp}^{-}$ring. ${ }^{8}$ In these cases the 51 anionic $\mathrm{N}$ or $\mathrm{C}$ centers significantly contribute to the stability of 52 the $\mathrm{Sc} / \mathrm{Y}-\mathrm{P}$ linkage. Here we report the synthesis and the first 53 detailed structural and spectroscopic data on complexes of $\mathrm{ScI}_{3} 54$ and $\mathrm{YI}_{3}$ with the neutral diphosphines $\mathrm{Me}_{2} \mathrm{PCH}_{2} \mathrm{CH}_{2} \mathrm{PMe}_{2}$ and 55 $o-\mathrm{C}_{6} \mathrm{H}_{4}\left(\mathrm{PMe}_{2}\right)_{2}$ and explore whether complexes with related 56 ligands or other scandium halides are accessible.

\section{EXPERIMENTAL SECTION}

58

All reactions were carried out using standard Schlenk and vacuum line 59 techniques. Samples were manipulated and stored in a glovebox and 60 under a dry dinitrogen atmosphere. Dichloromethane and acetonitrile 61 were distilled over $\mathrm{CaH}_{2}$ and diethyl ether and $n$-pentane from sodium 62 benzophenone ketyl. Anhydrous $\mathrm{ScI}_{3}$ was obtained from Sigma- 63 Aldrich and $\mathrm{YI}_{3}$ from Alfa, $\mathrm{Me}_{2} \mathrm{PCH}_{2} \mathrm{CH}_{2} \mathrm{PMe}_{2}, \mathrm{Ph}_{2} \mathrm{PCH}_{2} \mathrm{CH}_{2} \mathrm{PPh}_{2}, 64$ and $o-\mathrm{C}_{6} \mathrm{H}_{4}\left(\mathrm{PPh}_{2}\right)_{2}$ were obtained from Strem, and all were used as 65 received. $o-\mathrm{C}_{6} \mathrm{H}_{4}\left(\mathrm{PMe}_{2}\right)_{2}$ and $o-\mathrm{C}_{6} \mathrm{H}_{4}\left(\mathrm{AsMe}_{2}\right)_{2}$ were made by the 66 literature routes.

IR spectra were obtained as Nujol mulls on a PerkinElmer Spectrum 68 100 spectrometer. ${ }^{1} \mathrm{H}$ and ${ }^{31} \mathrm{P}\left\{{ }^{1} \mathrm{H}\right\}$ NMR spectra were recorded in 69 solution in anhydrous $\mathrm{CD}_{2} \mathrm{Cl}_{2}$ on a Bruker $\mathrm{AV} 400$ spectrometer and 70 referenced to residual solvent and external $\mathrm{H}_{3} \mathrm{PO}_{4}$, respectively. ${ }^{45} \mathrm{Sc} 71$ and ${ }^{89} \mathrm{Y}$ solution spectra were also recorded in the same solvent on a 72 Bruker AV 400 spectrometer.

Solid-state NMR experiments were performed at $14.1 \mathrm{~T}$ using an 74 Agilent DD2 $600 \mathrm{MHz}$ narrow-bore spectrometer, using 3.2 and 1.675 $\mathrm{mm}$ T3 triple-resonance probes. In all cases, samples were handled and 76 transferred into 1.6 or $3.2 \mathrm{~mm}$ zirconium oxide rotors using a 77 dinitrogen-filled glovebox. Unless otherwise specified, all measure- 78 ments were performed with magic-angle spinning (MAS) NMR 79 measurements under nitrogen, obtained from the boil-off of 80

Received: September 20, 2016 


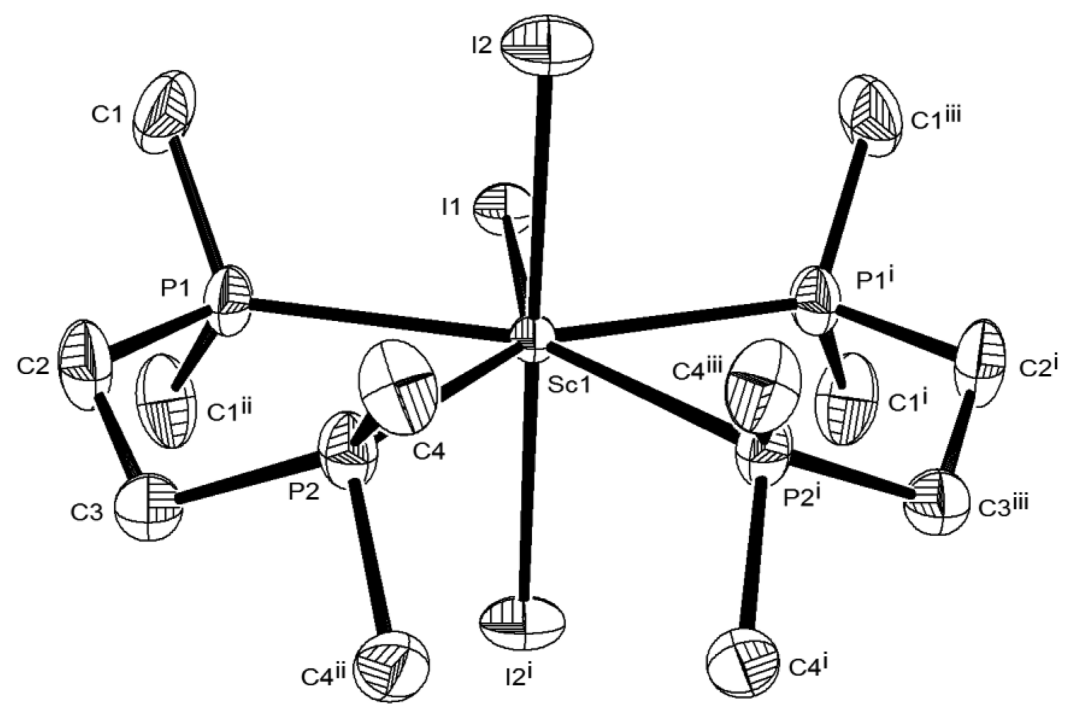

Figure 1. Structure of $\left[\mathrm{ScI}_{3}\left(\mathrm{Me}_{2} \mathrm{PCH}_{2} \mathrm{CH}_{2} \mathrm{PMe}_{2}\right)_{2}\right]$ with ellipsoids drawn at the $50 \%$ level and with the disorder omitted. Selected bond lengths $(\AA)$ and angles $(\mathrm{deg}): \mathrm{Sc}(1)-\mathrm{I}(1)=3.049(2), \mathrm{Sc}(1)-\mathrm{I}(2)=2.7686(7), \operatorname{Sc}(1)-\mathrm{P}(1)=2.7881(19), \operatorname{Sc}(1)-\mathrm{P}(2)=2.828(2) ; \mathrm{I}(2)-\mathrm{Sc}(1)-\mathrm{I}(1)=$ 93.16(4), I(2 $\left.2^{\mathrm{i}}\right)-\mathrm{Sc}(1)-\mathrm{I}(2)=173.67(7), \mathrm{I}(2)-\mathrm{Sc}(1)-\mathrm{P}(1)=90.944(9), \mathrm{I}(2)-\mathrm{Sc}(1)-\mathrm{P}(2)=87.49(3), \mathrm{P}(1)-\mathrm{Sc}(1)-\mathrm{P}(2)=69.97(6), \mathrm{P}(1)-$ $\mathrm{Sc}(1)-\mathrm{I}(1)=72.63(5), \mathrm{P}(2)-\mathrm{Sc}(1)-\mathrm{P}\left(2^{\mathrm{i}}\right)=74.80(9)$. Symmetry codes: (i) $1-x, 1.5-y, z$; (ii) $1-x, y, z$; (iii) $x, 1.5-y, z$.

81 pressurized liquid nitrogen, using the spinning frequency $\nu_{\mathrm{r}}=20 \mathrm{kHz}$. 82 The temperature was set to $293 \mathrm{~K}$ and was not further calibrated to 83 include small variations due to the sample spinning under MAS. 84 Measurements on ${ }^{31} \mathrm{P}$ were performed with direct excitation, with a 85 pulse delay of $3-5$ min between scans, sufficient to fully relax to 86 thermal equilibrium as verified experimentally. Measurements on ${ }^{45} \mathrm{Sc}$ 87 were performed with direct excitation using a $1 \mathrm{~s}$ pulse delay, using at 88 least two different spinning frequencies in order to identify the 89 position of the central band. Measurements on ${ }^{89} \mathrm{Y}$ were performed 90 using cross-polarization with 2048 scans, contact times in the range 91 between 10 and $20 \mathrm{~ms},{ }^{10}$ and a $10 \mathrm{~s}$ pulse delay, to transfer 92 magnetization from fast-relaxing neighboring ${ }^{1} \mathrm{H}$ spins in order to 93 overcome problems with the very long relaxation time of ${ }^{89} \mathrm{Y}$.

94 The ${ }^{31} \mathrm{P},{ }^{45} \mathrm{Sc}$, and ${ }^{89} \mathrm{Y}$ chemical shifts were referenced to $0 \mathrm{ppm}$ 95 using $85 \% \mathrm{H}_{3} \mathrm{PO}_{4}, \mathrm{Y}\left(\mathrm{NO}_{3}\right)_{3}$, and $\mathrm{Sc}\left(\mathrm{NO}_{3}\right)_{3}(0.1 \mathrm{M}$ in water adjusted 96 to $\mathrm{pH} 1$ with $\mathrm{HNO}_{3}$ ), respectively. ${ }^{11}$ Microanalyses were performed by 97 London Metropolitan University.

98 X-ray Experiments. Data collections used a Rigaku AFC12 99 goniometer equipped with an enhanced sensitivity (HG) Saturn724+ 100 detector mounted at the window of an FR-E+ SuperBright 101 molybdenum $(\lambda=0.71073 \AA)$ rotating anode generator with VHF 102 Varimax optics ( $70 \mu \mathrm{m}$ focus) with the crystal held at $100 \mathrm{~K}$. Structure 103 solution and refinement were performed using SHELX(S/L)97, 104 SHELX-2013, or SHELX-2014/7 and were straightforward ${ }^{12}$ except 105 for some disorder in the $\mathrm{CH}_{3}$ and $\mathrm{CH}_{2}$ groups of the diphosphine in 106 the structure of $\left[\mathrm{ScI}_{3}\left(\mathrm{Me}_{2} \mathrm{PCH}_{2} \mathrm{CH}_{2} \mathrm{PMe}_{2}\right)\right]$, which was satisfactorily 107 modeled with 50:50 split occupancies. $\mathrm{H}$ atoms were placed in 108 calculated positions. Details of the crystallographic parameters are 109 given in Table S1 in the Supporting Information. CCDC reference 110 numbers are CCDC 1479049-1479051.

111 Complex Synthesis. $\left[\mathrm{SCl}_{3}\left\{\mathrm{O}-\mathrm{C}_{6} \mathrm{H}_{4}\left(\mathrm{PMe}_{2}\right)_{2}\right\}_{2}\right]$. To a suspension of $112 \mathrm{ScI}_{3}(53 \mathrm{mg}, 0.125 \mathrm{mmol})$ in anhydrous acetonitrile $(5 \mathrm{~mL})$ was added $1130-\mathrm{C}_{6} \mathrm{H}_{4}\left(\mathrm{PMe}_{2}\right)_{2}(55 \mathrm{mg}, 0.27 \mathrm{mmol})$ with stirring. After 3 days when 114 everything had dissolved, the volatiles were removed in vacuo. The 115 white solid residue was washed with $n$-pentane to remove the excess 116 ligand, and the solid was dried in vacuo. Yield: $98 \mathrm{mg}$, 95\%. Colorless 117 single crystals were grown by slow evaporation from an acetonitrile 118 solution under $\mathrm{N}_{2}$. Anal. Calcd for $\mathrm{C}_{20} \mathrm{H}_{32} \mathrm{I}_{3} \mathrm{P}_{4} \mathrm{Sc}$ (822.03): C, 29.2; $\mathrm{H}$, 119 3.9. Found: $\mathrm{C}, 29.2 ; \mathrm{H}, 3.9 .{ }^{1} \mathrm{H}$ NMR $\left(\mathrm{CD}_{2} \mathrm{Cl}_{2}\right): 298 \mathrm{~K}, 1.99$ (s, $120[24 \mathrm{H}], \mathrm{Me}), 7.61(\mathrm{~m},[4 \mathrm{H}]$, aromatic $\mathrm{CH}), 7.78(\mathrm{~m},[4 \mathrm{H}]$, aromatic $121 \mathrm{CH}) ; 180 \mathrm{~K}, 1.93(\mathrm{~s},[24 \mathrm{H}], \mathrm{Me}), 7.62(\mathrm{~m},[4 \mathrm{H}]$, aromatic $\mathrm{CH}), 7.84$ $122(\mathrm{~m},[4 \mathrm{H}]$, aromatic $\mathrm{CH}) .{ }^{31} \mathrm{P}\left\{{ }^{1} \mathrm{H}\right\} \operatorname{NMR}\left(\mathrm{CD}_{2} \mathrm{Cl}_{2}\right): 293 \mathrm{~K},-20.8[\mathrm{P}]$, $123-25.8[\mathrm{P}] ; 180 \mathrm{~K},-21.6(\mathrm{~s}) .{ }^{45} \mathrm{Sc} \operatorname{NMR}\left(\mathrm{CD}_{2} \mathrm{Cl}_{2}\right): 293 \mathrm{~K},+371(\mathrm{~s})$; $124180 \mathrm{~K},+364(\mathrm{~s})$.
$\left[\mathrm{SCl}_{3}\left(\mathrm{Me}_{2} \mathrm{PCH}_{2} \mathrm{CH}_{2} \mathrm{PMe}_{2}\right)_{2}\right]$. To a suspension of $\mathrm{ScI}_{3}(53 \mathrm{mg}, 0.125125$ mmol) in dry acetonitrile $(5 \mathrm{~mL})$ was added $\mathrm{Me}_{2} \mathrm{PCH}_{2} \mathrm{CH}_{2} \mathrm{PMe}_{2}(40126$ $\mathrm{mg}, 0.26 \mathrm{mmol}$ ) with stirring. After the mixture was stirred for 3 days, 127 a completely clear solution had formed and the volatiles were then 128 removed in vacuo. The white solid residue was washed with $n$-pentane 129 to remove any excess ligand, and the solid was dried in vacuo. Yield: 80130 $\mathrm{mg}, 88 \%$. Colorless single crystals were grown by slow evaporation 131 from an acetonitrile solution under $\mathrm{N}_{2}$. Anal. Calcd for $\mathrm{C}_{12} \mathrm{H}_{32} \mathrm{I}_{3} \mathrm{P}_{4} \mathrm{Sc} 132$ (725.94): C, 19.8; H, 4.4. Found: C, 19.7; H, 4.4. ${ }^{1} \mathrm{H}$ NMR $\left(\mathrm{CD}_{2} \mathrm{Cl}_{2}, 133\right.$ $298 \mathrm{~K}): 1.97$ (s, $[24 \mathrm{H}], \mathrm{Me}), 2.33\left(\mathrm{~m},[8 \mathrm{H}], \mathrm{CH}_{2}\right) .{ }^{31} \mathrm{P}\left\{{ }^{1} \mathrm{H}\right\}$ NMR 134 $\left(\mathrm{CD}_{2} \mathrm{Cl}_{2}\right): 293 \mathrm{~K},-21.0(\mathrm{~s}) \mathrm{ppm} ; 180 \mathrm{~K},-14.9(\mathrm{~s}),-20.2(\mathrm{~s}) .{ }^{45} \mathrm{Sc} 135$ NMR $\left(\mathrm{CD}_{2} \mathrm{Cl}_{2}\right): 293 \mathrm{~K},+361(\mathrm{~s}) ; 180 \mathrm{~K},+362$ (s).

$\left.\left[\mathrm{YI}_{3} \mathrm{SO}_{\mathrm{O}} \mathrm{C}_{6} \mathrm{H}_{4}\left(\mathrm{PMe}_{2}\right)_{2}\right\}_{2}\left(\mathrm{CH}_{3} \mathrm{CN}\right)\right]$. To a suspension of $\mathrm{YI}_{3}$ (58 $\mathrm{mg}, 137$ $0.125 \mathrm{mmol})$ in dry acetonitrile $(5 \mathrm{~mL})$ was added $o-\mathrm{C}_{6} \mathrm{H}_{4}\left(\mathrm{PMe}_{2}\right)_{2} \quad 138$ (54 mg, $0.27 \mathrm{mmol}$ ) with stirring. After $12 \mathrm{~h}$ all the $\mathrm{YI}_{3}$ had dissolved 139 to give a clear solution, and hence the volatiles were removed in vacuo. 140 The white solid residue was washed with $n$-pentane to remove any 141 excess ligand, and the solid was dried in vacuo. Yield: $92 \mathrm{mg}, 90 \% .142$ Colorless single crystals were grown by slow evaporation from an 143 acetonitrile solution under $\mathrm{N}_{2}$. Anal. Calcd for $\mathrm{C}_{22} \mathrm{H}_{35} \mathrm{I}_{3} \mathrm{~N}_{1} \mathrm{P}_{4} \mathrm{Y} 144$ (907.03): C, 29.1; H, 3.8; N, 1.5. Found: C, 29.2; H, 3.7; N, 1.5. 145 ${ }^{1} \mathrm{H}$ NMR $\left(\mathrm{CD}_{2} \mathrm{Cl}_{2}\right): 298 \mathrm{~K}, 1.85(\mathrm{~s},[24 \mathrm{H}], \mathrm{Me}), 2.01\left(\mathrm{~s}, \mathrm{CH}_{3} \mathrm{CN}\right), 146$ $7.55(\mathrm{~m},[4 \mathrm{H}]$, aromatic $\mathrm{CH}), 7.81(\mathrm{~m},[4 \mathrm{H}]$, aromatic $\mathrm{CH}) ; 180 \mathrm{~K}, 147$ $1.78(\mathrm{~s}), 1.95(\mathrm{~s}), 7.50(\mathrm{~m}), 7.90(\mathrm{~m}) .{ }^{31} \mathrm{P}\left\{{ }^{1} \mathrm{H}\right\}$ NMR $\left(\mathrm{CD}_{2} \mathrm{Cl}_{2}\right): 293148$ $\mathrm{K},-38.3\left(\mathrm{~d},{ }^{1} J_{\mathrm{PY}}=37 \mathrm{~Hz}\right) ; 180 \mathrm{~K},-37.5\left(\mathrm{~d},{ }^{1} J_{\mathrm{PY}}=37 \mathrm{~Hz}\right) .{ }^{89} \mathrm{Y}$ NMR 149 $\left(\mathrm{CD}_{2} \mathrm{Cl}_{2}, 293 \mathrm{~K}\right)$ : not observed. IR $\left(\mathrm{Nujol} / \mathrm{cm}^{-1}\right)$ : 2313, 2276150 $(\mathrm{MeCN})$.

$\left[\mathrm{Yl}_{3}\left(\mathrm{Me}_{2} \mathrm{PCH}_{2} \mathrm{CH}_{2} \mathrm{PMe}_{2}\right)_{2}\right] . \mathrm{Me}_{2} \mathrm{PCH}_{2} \mathrm{CH}_{2} \mathrm{PMe}_{2}(40 \mathrm{mg}, 0.26 \mathrm{mmol})$ was added to a suspension of $\mathrm{YI}_{3}(58 \mathrm{mg}, 0.125 \mathrm{mmol})$ in anhydrous 153 acetonitrile $(5 \mathrm{~mL})$ with stirring. After $12 \mathrm{~h}$ a completely clear solution 154 was obtained and the volatiles were then removed in vacuo. The white 155 solid residue was washed with $n$-pentane to remove any excess ligand, 156 and the solid was dried in vacuo. Yield: $85 \mathrm{mg}, 88 \%$. Anal. Calcd for 157 $\mathrm{C}_{12} \mathrm{H}_{32} \mathrm{I}_{3} \mathrm{P}_{4} \mathrm{Y}$ (769.89): C, 18.7; H, 4.1. Found: C, 18.8; H, 4.6. ${ }^{1} \mathrm{H} 158$ NMR $\left(\mathrm{CD}_{2} \mathrm{Cl}_{2}\right): 298 \mathrm{~K}, 1.53(\mathrm{~s},[24 \mathrm{H}], \mathrm{Me}), 1.85\left(\mathrm{~m},[8 \mathrm{H}], \mathrm{CH}_{2}\right) ; 159$ $190 \mathrm{~K}, 1.47\left(\mathrm{~d},{ }^{2} \mathrm{~J}_{\mathrm{PH}}=19 \mathrm{~Hz}\right), 1.81(\mathrm{br}) .{ }^{31} \mathrm{P}\left\{{ }^{1} \mathrm{H}\right\} \operatorname{NMR}\left(\mathrm{CD}_{2} \mathrm{Cl}_{2}\right): 160$ $293 \mathrm{~K},-28.7$ (s); $190 \mathrm{~K},-23.3(\mathrm{~s}),-30.8(\mathrm{~s}) .{ }^{89} \mathrm{Y} \mathrm{NMR}\left(\mathrm{CD}_{2} \mathrm{Cl}_{2}, 161\right.$ $293 \mathrm{~K})$ : not observed.

\section{RESULTS AND DISCUSSION}

Complexes of $\mathrm{Scl}_{3}$ and $\mathrm{YI}_{3}$. Our initial studies used 164 anhydrous scandium(III) and yttrium(III) iodides as the metal 165 source, since previous work with lanthanide complexes of O/S- 166 


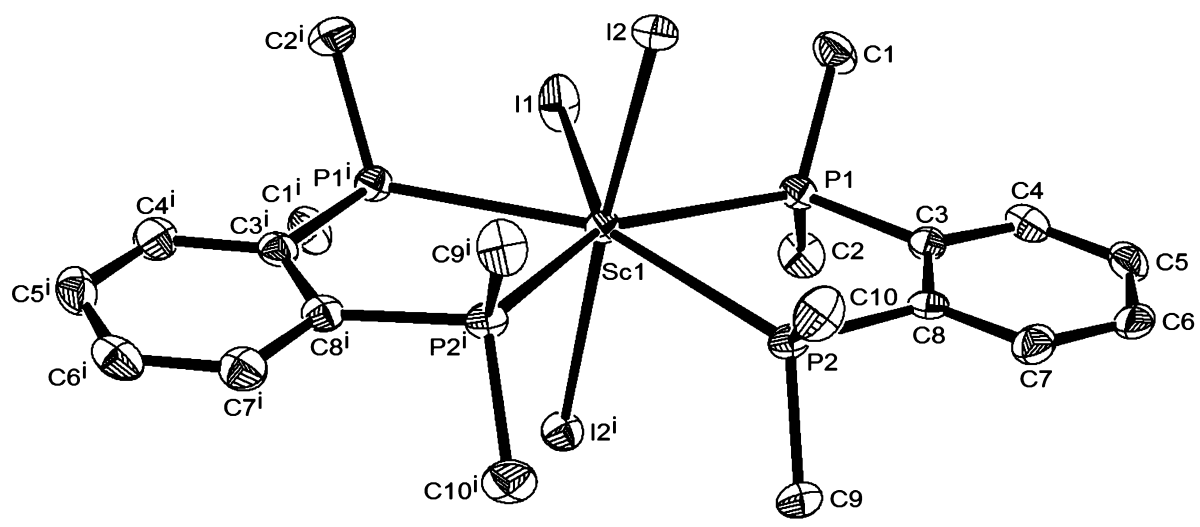

Figure 2. Structure of $\left[\mathrm{ScI}_{3}\left\{0-\mathrm{C}_{6} \mathrm{H}_{4}\left(\mathrm{PMe}_{2}\right)_{2}\right\}_{2}\right]$ with ellipsoids drawn at the $50 \%$ probability level. Selected bond lengths $(\AA)$ and angles (deg): $\mathrm{Sc}(1)-\mathrm{I}(1)=2.9226(13), \mathrm{Sc}(1)-\mathrm{I}(2)=2.8046(4), \mathrm{Sc}(1)-\mathrm{P}(1)=2.7767(11), \mathrm{Sc}(1)-\mathrm{P}(2)=2.8627(14) ; \mathrm{P}(1)-\mathrm{Sc}(1)-\mathrm{I}(2)=95.03(3), \mathrm{P}(1)-$ $\mathrm{Sc}(1)-\mathrm{I}\left(2^{\mathrm{i}}\right)=88.55(3), \mathrm{I}(2)-\mathrm{Sc}(1)-\mathrm{I}\left(2^{\mathrm{i}}\right)=168.59(5), \mathrm{P}(1)-\mathrm{Sc}(1)-\mathrm{P}(2)=69.72(3), \mathrm{I}(2)-\mathrm{Sc}(1)-\mathrm{P}(2)=85.25(3), \mathrm{I}(2)-\mathrm{Sc}(1)-\mathrm{P}\left(2^{\mathrm{i}}\right)=$ 85.85(3), $\mathrm{P}(1)-\mathrm{Sc}(1)-\mathrm{I}(1)=71.71(3), \mathrm{I}(2)-\mathrm{Sc}(1)-\mathrm{I}(1)=95.70(2) \mathrm{P}(2)-\mathrm{Sc}(1)-\mathrm{P}\left(2^{\mathrm{i}}\right)=77.31(5)$. Symmetry codes: (i) $x, y,-z$.

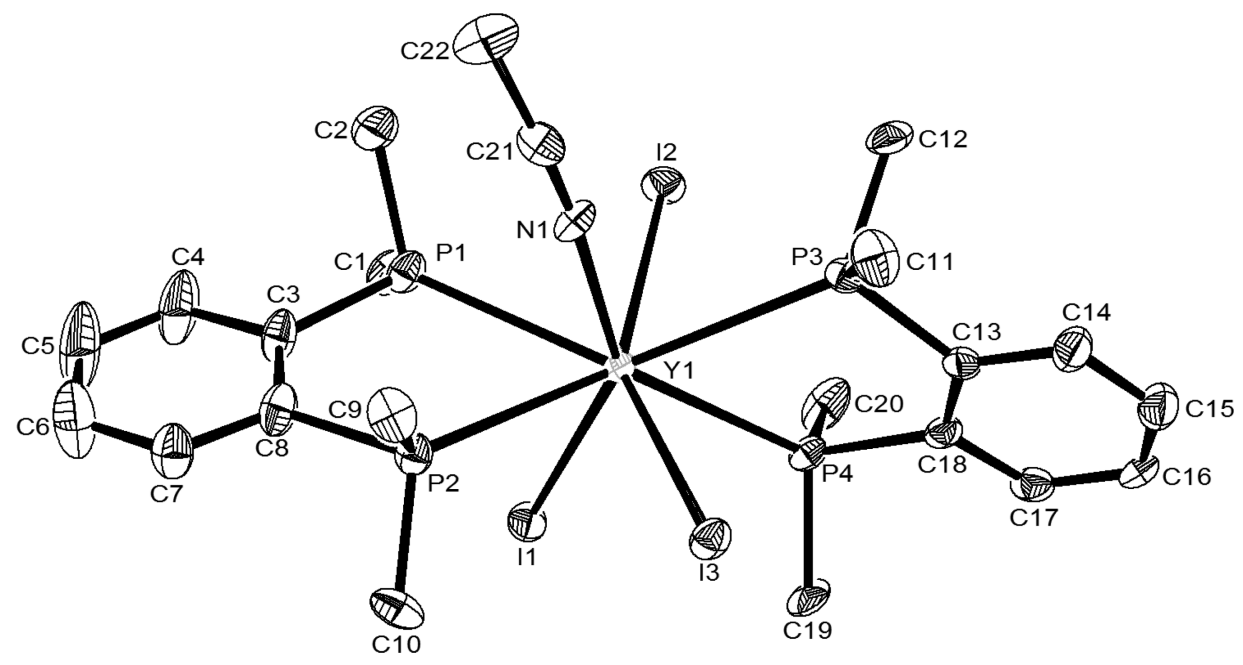

Figure 3. Structure of $\left[\mathrm{YI}_{3}\left\{o-\mathrm{C}_{6} \mathrm{H}_{4}\left(\mathrm{PMe}_{2}\right)_{2}\right\}_{2}\left(\mathrm{CH}_{3} \mathrm{CN}\right)\right]$ with ellipsoids at the $50 \%$ level. Selected bond lengths $(\AA)$ and angles $($ deg $): \mathrm{Y}(1)-\mathrm{I}(1)=$ 3.0197(12), $\mathrm{Y}(1)-\mathrm{I}(2)=3.0257(13), \mathrm{Y}(1)-\mathrm{I}(3)=3.0610(15), \mathrm{Y}(1)-\mathrm{N}(1)=2.428(9), \mathrm{Y}(1)-\mathrm{P}(4)=2.975(3), \mathrm{Y}(1)-\mathrm{P}(2)=3.019(3), \mathrm{Y}(1)-\mathrm{P}(1)$ $=3.023(3), \mathrm{Y}(1)-\mathrm{P}(3)=3.045(2) ; \mathrm{N}(1)-\mathrm{Y}(1)-\mathrm{P}(2)=74.0(2), \mathrm{N}(1)-\mathrm{Y}(1)-\mathrm{P}(1)=75.0(2), \mathrm{N}(1)-\mathrm{Y}(1)-\mathrm{I}(2)=85.5(2), \mathrm{N}(1)-\mathrm{Y}(1)-\mathrm{P}(3)=$ 73.5(2), $\mathrm{P}(2)-\mathrm{Y}(1)-\mathrm{P}(1)=65.87(8), \mathrm{I}(1)-\mathrm{Y}(1)-\mathrm{P}(1)=74.04(6), \mathrm{P}(4)-\mathrm{Y}(1)-\mathrm{I}(2)=80.19(6), \mathrm{I}(1)-\mathrm{Y}(1)-\mathrm{I}(2)=99.52(3), \mathrm{P}(1)-\mathrm{Y}(1)-\mathrm{I}(2)=$ 71.27(6), $\mathrm{P}(4)-\mathrm{Y}(1)-\mathrm{P}(3)=65.92(7), \mathrm{I}(2)-\mathrm{Y}(1)-\mathrm{P}(3)=76.39(5), \mathrm{N}(1)-\mathrm{Y}(1)-\mathrm{I}(3)=93.9(2), \mathrm{P}(4)-\mathrm{Y}(1)-\mathrm{I}(3)=79.72(6), \mathrm{P}(2)-\mathrm{Y}(1)-\mathrm{I}(3)$ $=73.17(6), \mathrm{I}(1)-\mathrm{Y}(1)-\mathrm{I}(3)=98.86(4), \mathrm{P}(3)-\mathrm{Y}(1)-\mathrm{I}(3)=73.18(6)$.

167 and O/Se-donor macrocycles, ${ }^{13}$ the trithia macrocycle [9]$168 \mathrm{aneS}_{3}{ }^{14}$ and zirconium(IV) and hafnium(IV) diphosphine 169 complexes $^{15}$ found that the iodides were better suited for 170 forming complexes of soft donor groups on the hard oxophilic 171 metal centers in comparison to the lighter halides. In addition, 172 the resulting complexes were often more soluble in weakly 173 coordinating solvents such as chlorocarbons, facilitating 174 spectroscopic studies of their properties. This probably largely 175 reflects the lower lattice energies of the metal iodides. The 176 reactions of anhydrous $\mathrm{ScI}_{3}$ with $\mathrm{Me}_{2} \mathrm{PCH}_{2} \mathrm{CH}_{2} \mathrm{PMe}_{2}$ or o$177 \mathrm{C}_{6} \mathrm{H}_{4}\left(\mathrm{PMe}_{2}\right)_{2}(\mathrm{~L}-\mathrm{L})$ in a 1:2 molar ratio in anhydrous $\mathrm{MeCN}$ 178 produced clear solutions, from which the colorless $\left[\mathrm{ScI}_{3}(\mathrm{~L}-\right.$ $\left.179 \mathrm{~L})_{2}\right]$ complexes were obtained after removing the solvent and 180 washing the residue with $n$-pentane. The same products were 181 isolated using a 1:3 M:L-L ratio. There is no evidence for 182 incorporation of $\mathrm{MeCN}$ in the IR spectra of the scandium 183 complexes. The synthesis and manipulation of these complexes 184 must be conducted with rigorous exclusion of air and moisture, 185 since water immediately displaces the diphosphine, while trace 186 dioxygen produces phosphine oxides. Formation of the latter is possibly promoted by the Lewis acidic center. ${ }^{16}$ Similar 187 reactions using $\mathrm{YI}_{3}$ produced $\left[\mathrm{YI}_{3}\{o-188\right.$ $\left.\left.\mathrm{C}_{6} \mathrm{H}_{4}\left(\mathrm{PMe}_{2}\right)_{2}\right\}_{2}\left(\mathrm{CH}_{3} \mathrm{CN}\right)\right]$ and $\left[\mathrm{YI}_{3}\left(\mathrm{Me}_{2} \mathrm{PCH}_{2} \mathrm{CH}_{2} \mathrm{PMe}_{2}\right)_{2}\right] 189$ (with no evidence for associated $\mathrm{MeCN}$ in the latter). Attempts 190 to isolate diphosphine complexes with the related 0 - 191 $\mathrm{C}_{6} \mathrm{H}_{4}\left(\mathrm{PPh}_{2}\right)_{2}$ and $\mathrm{Cy}_{2} \mathrm{PCH}_{2} \mathrm{CH}_{2} \mathrm{PCy}_{2}$ or with the diarsine $o-192$ $\mathrm{C}_{6} \mathrm{H}_{4}\left(\mathrm{AsMe}_{2}\right)_{2}$ using similar conditions were unsuccessful, and 193 we comment on the case of $\mathrm{Ph}_{2} \mathrm{PCH}_{2} \mathrm{CH}_{2} \mathrm{PPh}_{2}$ below.

Given the paucity of $\mathrm{Sc}$ (III) and Y(III) complexes with 195 phosphine ligands in the literature, it was imperative to obtain 196 crystallographic authentication for the new complexes. Crystals 197 suitable for X-ray analysis were obtained for 198 $\left[\mathrm{ScI}_{3}\left(\mathrm{Me}_{2} \mathrm{PCH}_{2} \mathrm{CH}_{2} \mathrm{PMe}_{2}\right)_{2}\right], \quad\left[\mathrm{ScI}_{3}\left\{o-\mathrm{C}_{6} \mathrm{H}_{4}\left(\mathrm{PMe}_{2}\right)_{2}\right\}_{2}\right]$, and 199 $\left[\mathrm{YI}_{3}\left\{o-\mathrm{C}_{6} \mathrm{H}_{4}\left(\mathrm{PMe}_{2}\right)_{2}\right\}_{2}\left(\mathrm{CH}_{3} \mathrm{CN}\right)\right]$, by slow evaporation of 200 acetonitrile solutions under nitrogen in a glovebox. The 201 structure of $\left[\mathrm{ScI}_{3}\left(\mathrm{Me}_{2} \mathrm{PCH}_{2} \mathrm{CH}_{2} \mathrm{PMe}_{2}\right)_{2}\right]$ (Figure 1) shows a $202 \mathrm{fl}$ seven-coordinate scandium center with a distorted-pentagonal- 203 bipyramidal coordination geometry, composed of a strictly 204 planar $\mathrm{P}_{4} \mathrm{I}$ pentagon and two axial iodide ligands. The latter 205 have short Sc-I distances of 2.7686(7) A, while the in-plane 206 
$207 d(\mathrm{Sc}-\mathrm{I})$ is markedly longer, at 3.049(2) $\AA$. These distances may 208 be compared with the $d(\mathrm{Sc}-\mathrm{I})$ of $2.915(2) \AA$ in the eight209 coordinate $\left[\mathrm{ScI}_{2}\left(18 \mathrm{aneO}_{4} \mathrm{~S}_{2}\right)\right] \mathrm{I} \quad\left([18] \mathrm{aneO}_{4} \mathrm{~S}_{2}=1,4,10,13-\right.$ 210 tetraoxa-7,16-dithiacyclooctadecane), which has a cis- $\mathrm{ScI}_{2}$ 211 unit. $^{13}$ The $d(\mathrm{Sc}-\mathrm{P})$ values are $2.7881(19)$ and 2.828(2) $\AA$, 212 and the chelate angle, $\angle \mathrm{P}-\mathrm{Sc}-\mathrm{P}$, is acute at $69.97(6)^{\circ}$. The $213 d(\mathrm{Sc}-\mathrm{P})$ values are similar to those observed ${ }^{7 \mathrm{a}}$ in the 214 complexes containing the PNP donor ligand $\left[\mathrm{Sc}\left(\eta^{5}-\mathrm{Cp}\right) \mathrm{X}\{\mathrm{N}-\right.$ $\left.\left.215\left(\mathrm{SiMe}_{2} \mathrm{CH}_{2} \mathrm{P}^{\mathrm{i}} \mathrm{Pr}_{2}\right)_{2}\right\}\right](\mathrm{X}=\mathrm{Ph}, \mathrm{Cl} ; 2.804(2)-2.836(2) \AA)$ and 216 organometallic scandium complexes with $\mathrm{PMe}_{3}$. ${ }^{6 \mathrm{~b}, \mathrm{c}}$

217 The structure of $\left[\mathrm{ScI}_{3}\left\{o-\mathrm{C}_{6} \mathrm{H}_{4}\left(\mathrm{PMe}_{2}\right)_{2}\right\}_{2}\right]$ (Figure 2) is also 218 pentagonal bipyramidal, but with a slightly more distorted 219 geometry, probably reflecting the more rigid backbone in the 220 diphosphine, although the $d(\mathrm{Sc}-\mathrm{I})$ and $d(\mathrm{Sc}-\mathrm{P})$ values are 221 very similar to those in $\left[\mathrm{ScI}_{3}\left(\mathrm{Me}_{2} \mathrm{PCH}_{2} \mathrm{CH}_{2} \mathrm{PMe}_{2}\right)_{2}\right]$ above. 222 Repeated attempts to obtain crystals of $223\left[\mathrm{YI}_{3}\left(\mathrm{Me}_{2} \mathrm{PCH}_{2} \mathrm{CH}_{2} \mathrm{PMe}_{2}\right)_{2}\right]$ were unsuccessful, but crystals of 224 the acetonitrile adduct $\left[\mathrm{YI}_{3}\left\{o-\mathrm{C}_{6} \mathrm{H}_{4}\left(\mathrm{PMe}_{2}\right)_{2}\right\}_{2}\left(\mathrm{CH}_{3} \mathrm{CN}\right)\right]$ were 225 obtained (Figure 3 ). The structure shows an eight-coordinate $\mathrm{Y}$ 226 center with a $\mathrm{P}_{4} \mathrm{I}_{3} \mathrm{~N}$ donor set. The geometry was shown to be 227 regular dodecahedral by identifying the plane of best fit which 228 encompassed the metal center and four of the eight 229 coordinating atoms and then calculating the dihedral angle 230 between this plane and the plane defined by the metal center 231 and the remaining four coordinating atoms (P1, P2, I2, and I3 232 form one plane and $\mathrm{P} 3, \mathrm{P} 4, \mathrm{I} 1$, and $\mathrm{N} 1$ form the second plane). 233 The value obtained was $89.8^{\circ}$, very close to the $90^{\circ}$ expected 234 for an ideal dodecahedron, whereas for an ideal square 235 antiprism this angle would be $77.4^{\circ} .{ }^{17}$

236 The $d(\mathrm{Y}-\mathrm{P})$ values of $2.975(3)-3.045(2) \AA$ are similar to 237 those found in yttrium complexes with the anionic PNP-donor 238 ligands, ${ }^{7 \mathrm{c}, \mathrm{e}}$ while the $d(\mathrm{Y}-\mathrm{I})$ values of $3.0197(12)-3.0610(15)$ $239 \AA$ are similar to those in $\left[\mathrm{YI}_{2}(\text { thf })_{5}\right]\left[\mathrm{YI}_{4}(\text { thf })_{2}\right](2.9685(6)-$ $2403.0181(6) \AA)^{18}$

241 The IR spectrum of $\left[\mathrm{YI}_{3}\left\{\left(o-\mathrm{C}_{6} \mathrm{H}_{4}\left(\mathrm{PMe}_{2}\right)_{2}\right\}_{2}\left(\mathrm{CH}_{3} \mathrm{CN}\right)\right]\right.$ 242 shows two bands at 2313 and $2276 \mathrm{~cm}^{-1}$, assigned as $\nu(\mathrm{CN})$ 243 and $\nu(\mathrm{C}-\mathrm{C})+\delta\left(\mathrm{CH}_{3}\right)$ of the coordinated nitrile, of similar 244 intensity due to Fermi resonance. ${ }^{19} \mathrm{CH}_{3} \mathrm{CN}$ itself (liquid film) 245 exhibits bands at 2293 and $2252 \mathrm{~cm}^{-1}$. It is notable that for the 246 other three complexes the IR spectra show no $\mathrm{CH}_{3} \mathrm{CN}$ present 247 and there is no evidence for phosphine oxides in any of the 248 complexes.

249 Solid-State and Solution NMR Spectra. Solid-state NMR 250 experiments were performed on these complexes under a 251 dinitrogen atmosphere, to probe both the phosphorus and the 252 metal site, and the results are shown in Figure 4 and Table 1. 253 The solid-state ${ }^{45} \mathrm{Sc}$ NMR spectra of both complexes were 254 broad singlets with very similar chemical shifts (see Figure $4 \mathrm{~b}$ 255 and Table 1, as well as Figure S1 in the Supporting Information 256 for the assignment of the center band of the ${ }^{45} \mathrm{Sc}$ spinning 257 sideband envelope). The complexes are extremely readily 258 hydrolyzed in solution, but ${ }^{45} \mathrm{Sc}$ NMR spectra were obtained 259 from freshly prepared and rigorously anhydrous solutions in $260 \mathrm{CH}_{2} \mathrm{Cl}_{2}$. The chemical shifts are slightly different from those 261 obtained for the solids. This provides very good evidence that 262 the same structures are retained in solution. We were unable to 263 observe ${ }^{89} \mathrm{Y}$ NMR resonances from $\mathrm{CH}_{2} \mathrm{Cl}_{2}$ solutions of either 264 yttrium complex at 295 or $180 \mathrm{~K}$. Despite its 100\% abundance 265 and $I=1 / 2,{ }^{89} \mathrm{Y}$ is a difficult nucleus to observe in solution, 266 with a low resonance frequency, poor receptivity, and very long $267 T_{1}$ values, and often exhibits some lability of the neutral ligands. 268 The modest solubility of the present complexes is also 269 unhelpful in the present cases. However, informative ${ }^{89} \mathrm{Y}$
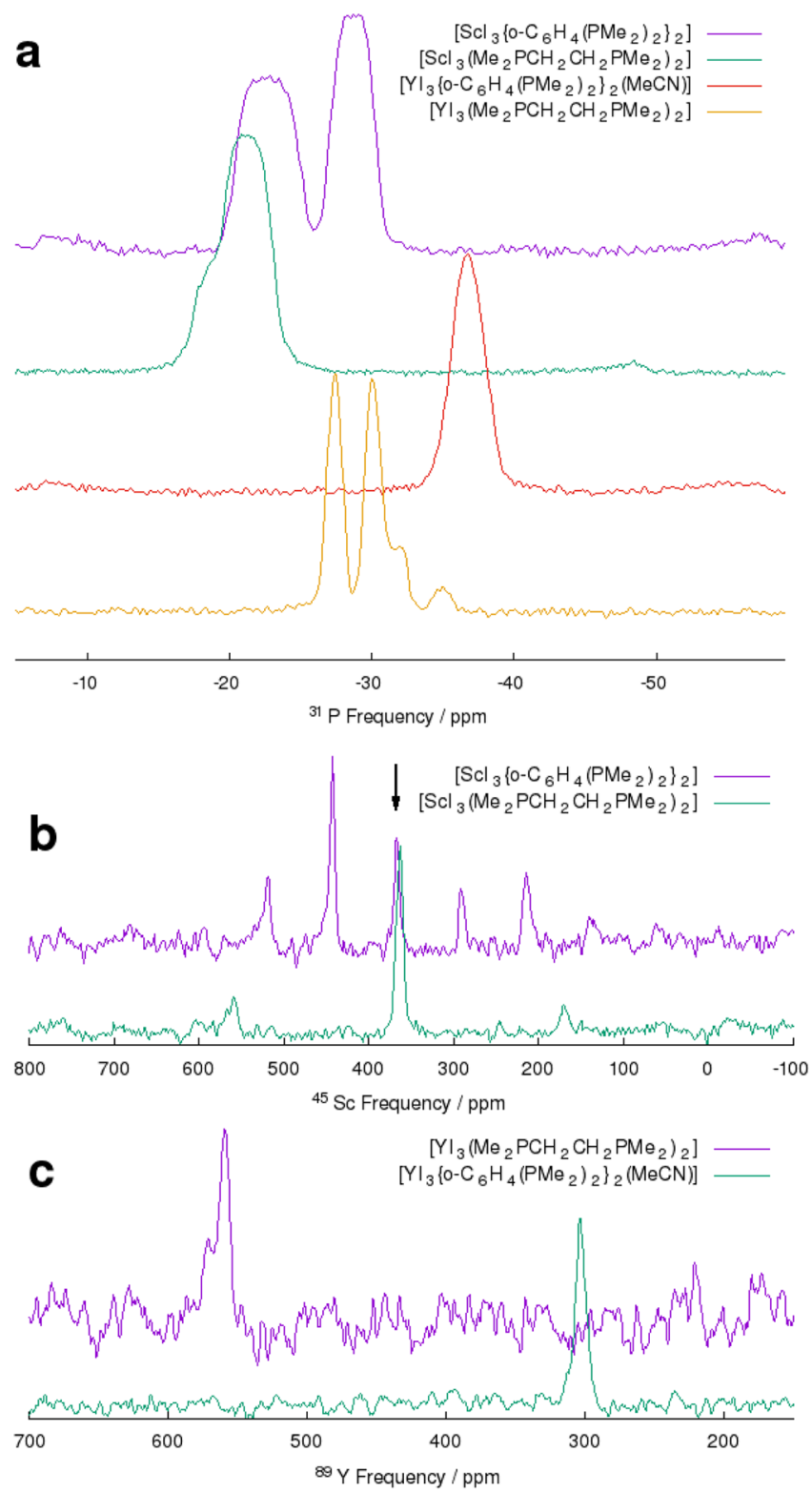

Figure 4. Experimental solid-state NMR spectra at $14.1 \mathrm{~T}$ under inert conditions for all samples and with MAS at $20 \mathrm{kHz}$ unless otherwise specified. Peak positions are summarized in Table 1 . (a) ${ }^{31} \mathrm{P}$ spectra acquired with direct excitation. (b) ${ }^{45} \mathrm{Sc}$ spectra, acquired with the following spin rates: $\left[\mathrm{ScI}_{3}\left\{o-\mathrm{C}_{6} \mathrm{H}_{4}\left(\mathrm{PMe}_{2}\right)_{2}\right\}_{2}\right]$ has $\nu_{\mathrm{r}}=11.1 \mathrm{kHz}$, and $\left[\mathrm{ScI}_{3}\left(\mathrm{Me}_{2} \mathrm{PCH}_{2} \mathrm{CH}_{2} \mathrm{PMe}_{2}\right)_{2}\right]$ has $\nu_{\mathrm{r}}=28 \mathrm{kHz}$, with the center-band position near $360 \mathrm{ppm}$ for both samples indicated by an arrow. (c) ${ }^{89} \mathrm{Y}$ spectra recorded with cross-polarization. One main site is clearly visible for both compounds.

MAS NMR spectra were obtained (Figure 4c) using cross- 270 polarization for the powdered solids, which partially overcomes 271 the limitations due to poor receptivity and slow relaxation. The 272 $\left[\mathrm{YI}_{3}\left\{o-\mathrm{C}_{6} \mathrm{H}_{4}\left(\mathrm{PMe}_{2}\right)_{2}\right\}_{2}\left(\mathrm{CH}_{3} \mathrm{CN}\right)\right]$ clearly shows a single peak 273 at $304 \mathrm{ppm}$, while for $\left[\mathrm{YI}_{3}\left(\mathrm{Me}_{2} \mathrm{PCH}_{2} \mathrm{CH}_{2} \mathrm{PMe}_{2}\right)_{2}\right]$ the main 274 resonance is at $559 \mathrm{ppm}$, possibly with a small shoulder to high 275 frequency.

The ${ }^{31} \mathrm{P}$ MAS NMR spectrum of $\left[\mathrm{ScI}_{3}\left\{o-\mathrm{C}_{6} \mathrm{H}_{4}\left(\mathrm{PMe}_{2}\right)_{2}\right\}_{2}\right] 277$ (Figure 4a) shows two well-resolved broad signals at -22.6 and 278 $-28.6 \mathrm{ppm}$ of similar intensity, which are likely to originate 279 from the inequivalent $\mathrm{P}$ environments seen in the crystal 280 structure. The ${ }^{31} \mathrm{P}$ MAS NMR spectrum of 281 
Table 1. Chemical Shifts (in ppm) As Obtained from Solution and Solid-State NMR Measurements at Ambient Temperature

$\begin{array}{lc} & {\left[\mathrm{ScI}_{3}\left\{o-\mathrm{C}_{6} \mathrm{H}_{4}\left(\mathrm{PMe}_{2}\right)_{2}\right\}_{2}\right]} \\ { }^{31} \mathrm{P} \text {, solid } & -22.6,-28.6 \\ & \\ { }^{31} \mathrm{P} \text {, soln } & -20.8,-25.8 \\ { }^{45} \mathrm{Sc} \text {, solid } & +366 \\ { }^{45} \mathrm{Sc} \text {, soln } & +371 \\ { }^{89} \mathrm{Y} \text {, solid } & \end{array}$

$\left[\mathrm{ScI}_{3}\left(\mathrm{Me}_{2} \mathrm{PCH}_{2} \mathrm{CH}_{2} \mathrm{PMe}_{2}\right)_{2}\right]$
$\quad-21.15$ (main)
$\quad-19.0$ (shoulder)
$\quad-21$
+362
+361

$\left[\mathrm{YI}_{3}\left\{\left(o-\mathrm{C}_{6} \mathrm{H}_{4}\left(\mathrm{PMe}_{2}\right)_{2}\right\}_{2}\left(\mathrm{CH}_{3} \mathrm{CN}\right)\right]\right.$
-36.7
-38.3

$\left[\mathrm{YI}_{3}\left(\mathrm{Me}_{2} \mathrm{PCH}_{2} \mathrm{CH}_{2} \mathrm{PMe}_{2}\right)_{2}\right]$

$-27.4,-30.0^{a}$

$-28.7$

304

559 (main)

570 (shoulder)

${ }^{a}$ Minor peaks at -31.9 and $-35 \mathrm{ppm}$ are attributed to a small amount of impurity, most likely resulting from decomposition during data acquisition.

$282\left[\mathrm{ScI}_{3}\left(\mathrm{Me}_{2} \mathrm{PCH}_{2} \mathrm{CH}_{2} \mathrm{PMe}_{2}\right)_{2}\right]$ shows a broad peak at -21.1 283 ppm, with a shoulder at -19 ppm.

284 For comparison, the solution ${ }^{31} \mathrm{P}\left\{{ }^{1} \mathrm{H}\right\}$ NMR spectrum of $285\left[\mathrm{ScI}_{3}\left\{o-\mathrm{C}_{6} \mathrm{H}_{4}\left(\mathrm{PMe}_{2}\right)_{2}\right\}_{2}\right]$ shows two broad and overlapping 286 resonances of similar intensity at -20.8 and $-25.8 \mathrm{ppm}$, 287 suggesting that the inequivalence of the $\mathrm{P}$ centers is retained in 288 solution. When the solution is cooled to $180 \mathrm{~K}$, this changes to 289 a single broad and asymmetric resonance at $-21.6 \mathrm{ppm}$. The 290 original spectrum is restored on warming the sample back to 291 ambient temperature. In contrast, the ${ }^{31} \mathrm{P}\left\{{ }^{1} \mathrm{H}\right\}$ NMR solution 292 spectrum of $\left[\mathrm{ScI}_{3}\left(\mathrm{Me}_{2} \mathrm{PCH}_{2} \mathrm{CH}_{2} \mathrm{PMe}_{2}\right)_{2}\right]$ at $295 \mathrm{~K}$ is a very 293 broad $\left(w_{1 / 2}=885 \mathrm{~Hz}\right)$ singlet, but at $180 \mathrm{~K}$ two resonances of $2941: 1$ intensity at -14.9 and $-20.1 \mathrm{ppm}$ are present, indicative of 295 inequivalent phosphorus centers. The single resonance at room 296 temperature in the latter probably indicates some fluxionality 297 (solution lability) — this is consistent with the complex bearing 298 the more flexible $\mathrm{Me}_{2} \mathrm{PCH}_{2} \mathrm{CH}_{2} \mathrm{PMe}_{2}$ (cf. that containing $o$ $\left.299 \mathrm{C}_{6} \mathrm{H}_{4}\left(\mathrm{PMe}_{2}\right)_{2}\right)$.

300 Moving to the yttrium complexes, ${ }^{31} \mathrm{P}$ MAS NMR spectros301 copy of $\left[\mathrm{YI}_{3}\left(\mathrm{Me}_{2} \mathrm{PCH}_{2} \mathrm{CH}_{2} \mathrm{PMe}_{2}\right)_{2}\right]$ exhibits two resonances of 302 equal intensity (Table 1 ) at -27.4 and $-30.0 \mathrm{ppm}$, consistent 303 with the structure being analogous to the scandium complex. 304 The ${ }^{31} \mathrm{P}\left\{{ }^{1} \mathrm{H}\right\}$ NMR solution spectrum of this complex displays 305 a singlet at $295 \mathrm{~K}(-28.7 \mathrm{ppm})$, but, like the scandium 306 analogue, at $180 \mathrm{~K}$ two singlets of equal intensity were present $307(-23.3,-30.8 \mathrm{ppm})$, attributed to inequivalent phosphorus 308 centers.

309 The ${ }^{31} \mathrm{P}$ MAS NMR spectrum of $\left[\mathrm{YI}_{3}\left\{o-\mathrm{C}_{6} \mathrm{H}_{4}\left(\mathrm{PMe}_{2}\right)_{2}\right\}_{2}\right)$ $310(\mathrm{MeCN})]$ shows a broad resonance at $-36.7 \mathrm{ppm}$, with no 311 observable coupling to ${ }^{89} \mathrm{Y}$ (the coupling constant determined 312 from the solution spectrum discussed below is smaller than the 313 line width in the solid sample). In contrast, the solution ${ }_{314}{ }^{31} \mathrm{P}\left\{{ }^{1} \mathrm{H}\right\}$ NMR spectra of this complex show a doublet $\left({ }^{1} J_{\mathrm{YP}}=\right.$ $31535 \mathrm{~Hz}$ ) at both 295 and $190 \mathrm{~K}$, which we attribute to coupling 316 to the $I=1 / 2{ }^{89} \mathrm{Y}$ nucleus.

317 Other Scandium Phosphine Complexes. The reaction of $318\left[\mathrm{ScCl}_{3}(\mathrm{MeCN})_{3}\right]$ with $o-\mathrm{C}_{6} \mathrm{H}_{4}\left(\mathrm{PMe}_{2}\right)_{2}$ in anhydrous $\mathrm{MeCN}$ 319 gave a white solid that was insoluble in, or decomposed by, 320 most donor solvents. In $\mathrm{CH}_{2} \mathrm{Cl}_{2}$ solution (in which it is only 321 sparingly soluble) it exhibited NMR spectra with $\delta\left({ }^{45} \mathrm{Sc}\right)+277$ 322 and $\delta\left({ }^{31} \mathrm{P}\right)$ as a very broad resonance with ill-defined couplings 323 at $\delta-22.6$, along with some uncoordinated diphosphine $(\delta$ $324-52)$. Addition of $\left[\mathrm{Me}_{4} \mathrm{~N}\right] \mathrm{Cl}$ to a $\mathrm{CH}_{2} \mathrm{Cl}_{2}$ solution of $\left[\mathrm{ScI}_{3}\{o-\right.$ $\left.\left.325 \mathrm{C}_{6} \mathrm{H}_{4}\left(\mathrm{PMe}_{2}\right)_{2}\right\}_{2}\right]$ gave a white precipitate, but the supernatant 326 solution showed ${ }^{45} \mathrm{Sc}$ and ${ }^{31} \mathrm{P}\left\{{ }^{1} \mathrm{H}\right\}$ NMR resonances similar to 327 those observed in the sample made from $\left[\mathrm{ScCl}_{3}(\mathrm{MeCN})_{3}\right]$ with $328 o-\mathrm{C}_{6} \mathrm{H}_{4}\left(\mathrm{PMe}_{2}\right)_{2}$. The common product is probably $\left[\mathrm{ScCl}_{3}\{o-\right.$ $\left.\left.329 \mathrm{C}_{6} \mathrm{H}_{4}\left(\mathrm{PMe}_{2}\right)_{2}\right\}_{2}\right]$, but due to its limited stability and very poor 330 solubility in chlorocarbons, we were unable to isolate a pure 331 sample. Similar treatment of a $\mathrm{CH}_{2} \mathrm{Cl}_{2}$ solution of $\left[\mathrm{ScI}_{3}\{o-\right.$ $\left.\left.332 \mathrm{C}_{6} \mathrm{H}_{4}\left(\mathrm{PMe}_{2}\right)_{2}\right\}_{2}\right]$ with $\left[\mathrm{Me}_{4} \mathrm{~N}\right] \mathrm{Br}$ gave a solution which exhibited multiple ${ }^{31} \mathrm{P}$ NMR resonances in the range $\delta-19333$ to -27 and ${ }^{45} \mathrm{Sc}$ resonances at $\delta-359,-335,-313$ and $-293 ; 334$ we attribute the resonance at $\delta-359$ to unchanged $\left[\mathrm{ScI}_{3}\{0-335\right.$ $\left.\left.\mathrm{C}_{6} \mathrm{H}_{4}\left(\mathrm{PMe}_{2}\right)_{2}\right\}_{2}\right]$ and the other three resonances to 336 $\left[\mathrm{ScI}_{3-n} \mathrm{Br}_{n}\left\{o-\mathrm{C}_{6} \mathrm{H}_{4}\left(\mathrm{PMe}_{2}\right)_{2}\right\}_{2}\right](n=1-3)$. This is consistent 337 with the hard Lewis acidic $\mathrm{Sc}$ (III) center showing a clear 338 preference for chloride over iodide ligands, while the 339 discrimination is less between $\mathrm{Br}$ and $\mathrm{I}$. In contrast, addition 340 of $\left[\mathrm{Me}_{4} \mathrm{~N}\right] \mathrm{F}$ to a $\mathrm{CH}_{2} \mathrm{Cl}_{2}$ solution of $\left[\mathrm{ScI}_{3}\left\{o-\mathrm{C}_{6} \mathrm{H}_{4}\left(\mathrm{PMe}_{2}\right)_{2}\right\}_{2}\right] 341$ instantly precipitates $\mathrm{ScF}_{3}$ and liberates the diphosphine. ${ }^{20}{ }_{342}$

We also reacted $\mathrm{ScCl}_{3}$ and $\mathrm{ScI}_{3}$ with $\mathrm{Ph}_{2} \mathrm{PCH}_{2} \mathrm{CH}_{2} \mathrm{PPh}_{2} 343$ under conditions similar to those described by Greenwood and 344 Tranter: ${ }^{5}$ i.e., reaction over several days in a large volume of 345 anhydrous $\mathrm{CHCl}_{3}$ containing $\sim 1 \%$ thf, followed by filtration to 346 remove the residual insoluble material. The filtrate was taken to 347 dryness and washed with large amounts of hot $n$-pentane. The 348 products were white solids with highly variable analytical 349 composition. They were partially soluble in $\mathrm{CH}_{2} \mathrm{Cl}_{2}$, the 350 solutions revealing ${ }^{31} \mathrm{P}\left\{{ }^{1} \mathrm{H}\right\}$ NMR resonances due to 351 $\mathrm{Ph}_{2} \mathrm{PCH}_{2} \mathrm{CH}_{2} \mathrm{PPh}_{2}$ and $\left[\mathrm{Ph}_{2} \mathrm{PCH}_{2} \mathrm{CH}_{2} \mathrm{PPh}_{2} \mathrm{H}\right]^{+}$with wide 352 variation between the relative amounts in different batches. 353 Notably, neither the NMR spectra nor the IR spectra showed 354 evidence for phosphine oxides. Although the evidence is 355 indicative rather than proof, it seems that the reported $\mathrm{ScX}_{3}-356$ $\mathrm{Ph}_{2} \mathrm{PCH}_{2} \mathrm{CH}_{2} \mathrm{PPh}_{2}$ "complexes" were most likely mixtures of 357 $\mathrm{ScX}_{3}$, diphosphine, and phosphonium haloscandate salts. We 358 note that phosphonium or sulfonium halometalates are 359 commonly formed under anhydrous conditions, as well as, or 360 instead of, metal complexes of the neutral ligand by reactions of 361 phosphines or thioethers with very hard Lewis acids. ${ }^{21} 362$

\section{CONCLUSIONS}

363

The preparations of the first authenticated diphosphine 364 complexes of scandium and yttrium trihalides have been 365 achieved and the products characterized both in the solid state 366 via both X-ray crystallographic studies and solid-state ${ }^{31} \mathrm{P},{ }^{45} \mathrm{Sc} 367$ and ${ }^{89} \mathrm{Y}$ NMR measurements and in solution by variable- 368 temperature multinuclear NMR spectroscopy. The chemical 369 shift variations on the scandium site as a function of the 370 diphosphine ligand are negligible, consistent with the two 371 phosphines having similar $\sigma$-donor properties. When we look at 372 the Y complexes, there is a significant variation in the ${ }^{89} \mathrm{Y}$ NMR 373 shifts, probably originating from the extra MeCN ligand present 374 and the resulting differences in the donor environment at 375 yttrium and coordination geometries present. $\mathrm{Ab}$ initio and 376 experimental data on ${ }^{89} \mathrm{Y}$ clearly highlight the problem of 377 relating observed shifts with particular patterns in ligands or 378 specific donor-acceptor interactions present. $^{22} \quad 379$

Evidence is also presented for the existence of complexes of 380 $o-\mathrm{C}_{6} \mathrm{H}_{4}\left(\mathrm{PMe}_{2}\right)_{2}$ with $\mathrm{ScCl}_{3}$ and $\mathrm{ScBr}_{3}$, although these were not 381 
382 isolated in a pure form. Other diphosphines with sterically small 383 alkyl substituents will likely also form analogous complexes. 384 The early report of scandium complexes of the much more 385 weakly donating $\mathrm{Ph}_{2} \mathrm{PCH}_{2} \mathrm{CH}_{2} \mathrm{PPh}_{2}$ ligand has been shown to 386 almost certainly be erroneous. Complexes with the softer and 387 less strongly $\sigma$ donating aryl diphosphine $o-\mathrm{C}_{6} \mathrm{H}_{4}\left(\mathrm{PPh}_{2}\right)_{2}$ or the 388 diarsine $o-\mathrm{C}_{6} \mathrm{H}_{4}\left(\mathrm{AsMe}_{2}\right)_{2}$ do not appear to form.

\section{ASSOCIATED CONTENT}

\section{S Supporting Information}

391 The Supporting Information is available free of charge on the 392 ACS Publications website at DOI: 10.1021/acs.inorg393 chem.6b02268.

\begin{tabular}{|c|c|}
\hline $\begin{array}{l}394 \\
395\end{array}$ & $\begin{array}{l}\text { Crystallographic data for }\left[\mathrm{ScI}_{3}\left\{o-\mathrm{C}_{6} \mathrm{H}_{4}\left(\mathrm{PMe}_{2}\right)_{2}\right\}_{2}\right] \\
(\mathrm{CCDC} 1479049)(\mathrm{CIF})\end{array}$ \\
\hline 396 & Crystallographic data \\
\hline 397 & $\left.\mathrm{C}_{6} \mathrm{H}_{4}\left(\mathrm{PMe}_{2}\right)_{2}\right\}_{2}(\mathrm{MeCN})(\mathrm{CCDC} 1479050)(\mathrm{CIF})$ \\
\hline 398 & $\begin{array}{l}\text { Crystallographic data for }\left[\mathrm{ScI}_{3}\left(\mathrm{Me}_{2} \mathrm{PCH}_{2} \mathrm{CH}_{2} \mathrm{PMe}_{2}\right)\right. \\
(\mathrm{CCDC} 1479051)(\mathrm{CIF})\end{array}$ \\
\hline & $\begin{array}{l}\text { Spectra supporting the assignment of the scandium } \\
\text { resonances in the MAS NMR data and data for the X-ray } \\
\text { data collection (PDF) }\end{array}$ \\
\hline
\end{tabular}

\section{AUTHOR INFORMATION}

\section{Corresponding Author}

405 *G.R.: e-mail, G.Reid@soton.ac.uk; tel, (44) 02380593601. 406 ORCID

407 Gillian Reid: 0000-0001-5349-3468

\section{Notes}

409 The authors declare no competing financial interest.

\section{ACKNOWLEDGMENTS}

411 We thank the EPSRC for support via the SCFED project 412 through a Programme Grant (EP/1033394/1), and also 413 through EP/K039466/1 and EP/M023664/1. MCa thanks 414 the Royal Society for a University Research Fellowship. The 415 SCFED Project (http://www.scfed.net) is a multidisciplinary 416 collaboration of British universities investigating the funda417 mental and applied aspects of supercritical fluids.

\section{$418 \square$ REFERENCES}

419 (1) (a) Comprehensive Coordination Chemistry II; McCleverty, J. A., 420 Meyer, T. J., Eds.; Elsevier: Oxford, U.K., 2004; Vols. 3-6. (b) The 421 Chemistry of Organophosphorus Compounds; Hartley, F. R., Ed.; Wiley: 422 New York, 1990; Vol. 1. (c) van Leeuwen, P. W. N. M. Homogeneous 423 Catalysis, Understanding the Art; Kluwer Academic: Dordrecht, The 424 Netherlands, 2004. (d) Crabtree, R. H. The Organometallic Chemistry 425 of the Transition Metals, 4th ed.; Wiley: New York, 2005.

426 (2) Burt, J.; Levason, W.; Reid, G. Coordination chemistry of the 427 main group elements with phosphine, arsine and stibine ligands. Coord. 428 Chem. Rev. 2014, 260, 65-115.

429 (3) (a) Frenking, G.; Holzmann, N.; Neumúller, B.; Dehnicke, K. $430\left[\mathrm{BeCl}_{2}\left(\mathrm{Ph}_{2} \mathrm{PCH}_{2} \mathrm{PPh}_{2}\right)_{2}\right]$ - ein Donor-Akzeptorkomplex des Ber431 ylliums mit dem Bis(diphenylphosphanyl)methan-Liganden. Z. Anorg. 432 Allg. Chem. 2010, 636, 1772-1775. (b) Braunschweig, H.; Gruss, K. 433 Synthesis and Structural Characterization of the Dinuclear Beryllium 434 Species $\left[\mathrm{Be}_{2} \mathrm{Cl}_{2}(\mu-\mathrm{Cl})_{2}\left(\mathrm{PCy}_{3}\right)_{2}\right]$. Z. Naturforsch., B: J. Chem. Sci. 2011, $43566,0055$.

436 (4) Carravetta, M.; Concistre, M.; Levason, W.; Reid, G.; Zhang, W. 437 Unique Group 1 cations stabilised by homoleptic neutral phosphine 438 coordination. Chem. Commun. 2015, 51, 9555-9558.
(5) Greenwood, N. N.; Tranter, R. L. Vibrational spectra of 439 anhydrous scandium(III) chloride and bromide and their complexes. J. 440 Chem. Soc. A 1969, 2878-2883.

(6) (a) Fryzuk, M. D.; Haddad, T. S.; Berg, D. J. Complexes of 442 groups 3, 4, the lanthanides and the actinides containing neutral donor 443 ligands. Coord. Chem. Rev. 1990, 99, 137-212. (b) Shapiro, P. J.; 444 Cotter, W. D.; Schaeffer, W. P.; Labinger, J. A.; Bercaw, J. E. Model 445 Ziegler-Natta $\alpha$-Olefin Polymerization Catalysts Derived from $\left[\left\{\left(\eta^{5}-446\right.\right.\right.$ $\left.\left.\left.\mathrm{C}_{5} \mathrm{Me}_{4}\right) \mathrm{SiMe}_{2}\left(\eta^{1}-\mathrm{NCMe}_{3}\right)\right\}\left(\mathrm{PMe}_{3}\right) \mathrm{Sc}\left(\mu_{2}-\mathrm{H}\right)\right]_{2}$ and $\left[\left\{\left(\eta^{5}-\mathrm{C}_{5} \mathrm{Me}_{4}\right)-447\right.\right.$ $\left.\left.\mathrm{SiMe}_{2}\left(\eta^{1}-\mathrm{NCMe}_{3}\right)\right\} \mathrm{Sc}\left(\mu_{2}-\mathrm{CH}_{2} \mathrm{CH}_{2} \mathrm{CH}_{3}\right)\right]_{2}$. Synthesis, Structures, and 448 Kinetic and Equilibrium Investigations of the Catalytically Active 449 Species in Solution. J. Am. Chem. Soc. 1994, 116, 4623-4640. 450 (c) Piers, W. E.; Ferguson, G.; Gallagher, J. F. Sterically Enforced 451 Linearity in a Bridging Telluride Ligand. X-ray Structure of 452 $\left\{\left(\mathrm{CH}_{3}\right)_{2} \mathrm{Si}\left[\left(t-\mathrm{C}_{4} \mathrm{H}_{9}\right) \mathrm{C}_{5} \mathrm{H}_{3}\right]_{2} \mathrm{Sc}\left(\mathrm{PMe}_{3}\right)\right\}_{2}(\mu-\mathrm{Te}) \cdot \mathrm{C}_{6} \mathrm{H}_{6}$. Inorg. Chem. 453 1994, 33, 3784-3787. (d) Stults, S.; Zalkin, A. Structure of Tris $(\eta-454$ methylcyclopentadienyl) (trimethylphosphine)cerium(III). Acta Crys- 455 tallogr., Sect. C: Cryst. Struct. Commun. 1987, 43, 430-432. 456

(7) (a) Fryzuk, M. D.; Giesbrecht, G. R.; Rettig, S. J. Synthesis, 457 characterization, and reactivity of scandium chloro, alkyl, aryl, and 458 borohydride complexes, $\mathrm{Sc}\left(\eta^{5}-\mathrm{C}_{5} \mathrm{H}_{5}\right) \mathrm{R}\left[\mathrm{N}\left(\mathrm{SiMe}_{2} \mathrm{CH}_{2} \mathrm{P}^{\mathrm{i}} \mathrm{Pr}_{2}\right)_{2}\right](\mathrm{R}=\mathrm{Cl}, 459$ $\mathrm{Me}, \mathrm{Ph}$, and $\mathrm{BH}_{4}$ ). Can. J. Chem. 2000, 78, 1003-1012. (b) Fryzuk, M. 460 D.; Giesbrecht, G. R.; Rettig, S. J. Synthesis and Characterization of 461 the Five-Coordinate Scandium Dialkyl Complexes $\mathrm{ScR}_{2}[\mathrm{~N}-462$ $\left.\left(\mathrm{SiMe}_{2} \mathrm{CH}_{2} \mathrm{PPr}_{2}^{\mathrm{i}}\right)_{2}\right]\left(\mathrm{R}=\mathrm{Me}, \mathrm{Et}, \mathrm{CH}_{2} \mathrm{SiMe}_{3}\right)$. Organometallics 1996, 463 15, 3329-3336. (c) Fryzuk, M. D.; Jafarpour, L.; Kerton, F. M.; Love, 464 J. B.; Patrick, B. O.; Rettig, S. J. Carbon-Carbon Bond Formation 465 Using Yttrium(III) and the Lanthanide Elements. Organometallics 466 2001, 20, 1387-1396. (d) Fryzuk, M. D.; Haddad, T. S. Phosphine 467 complexes of yttrium(III). Synthesis, reactivity and fluxional behavior 468 of $\mathrm{YCl}\left[\mathrm{N}\left(\mathrm{SiMe}_{2} \mathrm{CH}_{2} \mathrm{PMe}_{2}\right)_{2}\right]_{2}$. J. Am. Chem. Soc. 1988, 110, 8263- 469 8265. (e) Fryzuk, M. D.; Haddad, T. S.; Rettig, S. J. Phosphine 470 complexes of yttrium, lanthanum, and lutetium. Synthesis, thermolysis, 471 and fluxional behavior of the hydrocarbyl derivatives $\mathrm{MR}[\mathrm{N}-472$ $\left.\left(\mathrm{SiMe}_{2} \mathrm{CH}_{2} \mathrm{PMe}_{2}\right)_{2}\right]_{2}$. X-ray crystal structure of [cyclic] $\mathrm{Y}[\mathrm{N}-473$ $\left.\left(\mathrm{SiMe}_{2} \mathrm{CHPMe}_{2}\right)\left(\mathrm{SiMe}_{2} \mathrm{CH}_{2} \mathrm{PMe}_{2}\right)\right]\left[\mathrm{N}\left(\mathrm{SiMe}_{2} \mathrm{CH}_{2} \mathrm{PMe}_{2}\right)_{2}\right]$. Organo- 474 metallics 1991, 10, 2026-2036. (f) Levine, D. S.; Tilley, T. D.; 475 Andersen, R. A. C-H Bond Activations by Monoanionic, PNP- 476 Supported Scandium Dialkyl Complexes. Organometallics 2015, 34, 477 4647-4655. (g) Wicker, B. F.; Fan, H.; Hickey, A. K.; Crestani, M. G.; 478 Scott, J.; Pink, M.; Mindiola, D. J. Evidence for the Existence of 479 Terminal Scandium Imidos: Mechanistic Studies Involving Imido- 480 Scandium Bond Formation and $\mathrm{C}-\mathrm{H}$ Activation Reactions. J. Am. 481 Chem. Soc. 2012, 134, 20081-20096. (h) Wicker, B. F.; Scott, J.; 482 Andino, J. G.; Gao, X.; Park, H.; Pink, M.; Mindiola, D. J. 483 Phosphinidene complexes of scandium: powerful Par group-transfer 484 vehicles to organic and inorganic substrates. J. Am. Chem. Soc. 2010, 485 132, 3691-3693. (i) Levine, D. S.; Tilley, T. D.; Andersen, R. A. C-H 486 Bond activations by monoanionic, PNP-supported scandium dialkyl 487 complexes. Organometallics 2015, 34, 4647-4655.

(8) (a) Karsch, H. H.; Graf, V. W.; Scherer, W. Phosphane 489 coordination to rare earth metal centers: monomeric, solvent-free 490 complexes of type $\mathrm{Cp}^{\prime}{ }_{2} \mathrm{LnX}$ with phosphanoethyl substituted cyclo- 491 pentadienyl ligands. J. Organomet. Chem. 2000, 604, 72-82. (b) Karsch, 492 H. H.; Graf, W.; Reisky, M.; Witt, E. Dimethylphosphanylethylcyclo- 493 pentadienyl Complexes of Lanthanum and Yttrium. Eur. J. Inorg. Chem. 494 1998, 1998, 1404-1406.

(9) (a) Kyba, E. P.; Liu, S. T.; Harris, R. L. A facile synthesis of 1,2- 496 bis(phosphino)benzene and related alkylated species. Organometallics 497 1983, 2, 1877-1879. (b) Feltham, R. D.; Kasenally, A.; Nyholm, R. S. 498 A new synthesis of di- and tri-tertiary arsines. J. Organomet. Chem. 499 1967, 7, 285-288.

500

(10) Wu, J.; Boyle, T. J.; Shreeve, J. L.; Ziller, J. W.; Evans, W. J. CP/ 501 MAS yttrium-89 NMR spectroscopy: a facile method for character- 502 izing yttrium-containing solids. Inorg. Chem. 1993, 32, 1130-1134. 503

(11) Harris, R. K.; Becker, E. D.; Cabral de Menezes, S. M.; 504 Goodfellow, R. J.; Granger, P. NMR nomenclature. Nuclear spin 505 properties and conventions for chemical shifts (IUPAC Recommen- 506 dations 2001). Pure Appl. Chem. 2001, 73, 1795-1818. 
508 (12) Sheldrick, G. M. Crystal structure refinement with SHELXL. 509 Acta Crystallogr., Sect. C: Struct. Chem. 2015, 71, 3-8. X CrystalClear510 SM Expert 3.1 b27; Rigaku Corporation, Tokyo, Japan, 2012. 511 CrystalClear-SM Expert 2.1 b29; Rigaku Corporation, Tokyo, Japan, 512 2013. CrysAlis PRO; Agilent Technologies Ltd., Yarnton, Oxforshire, 513 England.

514 (13) Champion, M. J. D.; Farina, P.; Levason, W.; Reid, G. Trivalent 515 scandium, yttrium and lanthanide complexes with thia-oxa and Selena516 oxa macrocycles and crown ether coordination. Dalton Trans. 2013, 517 42, 13179-13189.

518 (14) Karmazin, L.; Mazzanti, M.; Pecaut, J. Unique crown thioether 519 complexes of $f$ elements: the crystal structure of $\mathrm{U}(\mathrm{III})$ and $\mathrm{La}$ (III) 520 complexes of 1,4,7-trithiacyclononane. Chem. Commun. 2002, 654521655 .

522 (15) Levason, W.; Matthews, M. L.; Patel, B.; Reid, G.; Webster, M. 523 Synthesis, properties and structures of eight-coordinate zirconium(IV) 524 and hafnium(IV) halide complexes with phosphorus and arsenic 525 ligands. Dalton Trans. 2004, 3305-3312.

526 (16) Levason, W.; Patel, R.; Reid, G. Catalytic air oxidation of tertiary 527 arylphosphines in the presence of tin(IV) iodide. J. Organomet. Chem. 528 2003, 688, 280-282.

529 (17) Lippard, S. J.; Russ, B. J. Comment on the choice of an eight530 coordinate polyhedron. Inorg. Chem. 1968, 7, 1686-1688.

531 (18) Izod, K.; Liddle, S. T.; Clegg, W. A Convenient Route to 532 Lanthanide Triiodide THF Solvates. Crystal Structures of $\mathrm{LnI}_{3}(\mathrm{THF})_{4}$ $533[\mathrm{Ln}=\mathrm{Pr}]$ and $\mathrm{LnI}_{3}(\mathrm{THF})_{3.5}[\mathrm{Ln}=\mathrm{Nd}, \mathrm{Gd}, \mathrm{Y}]$. Inorg. Chem. 2004, 43, $534214-218$.

535 (19) Swanson, B.; Shriver, D. F. Vibrational spectra, vibrational 536 analysis and bonding in acetonitrile-boron trifluoride. Inorg. Chem. 537 1970, 9, 1406-1416.

538 (20) Benjamin, S. L.; Levason, W.; Reid, G. Medium and high 539 oxidation state metal/non-metal fluoride and oxide-fluoride com540 plexes with neutral donor ligands. Chem. Soc. Rev. 2013, 42, 14605411499.

542 (21) Leading references: (a) Jura, M.; Levason, W.; Petts, E.; Reid, 543 G.; Webster, M.; Zhang, W. Taking TiF4 complexes to extremes - the 544 first examples with phosphine co-ligands. Dalton Trans. 2010, 39, 545 10264-10271. Jura, M.; Levason, W.; Reid, G.; Webster, M. Isolation 546 and structures of sulfonium salts derived from thioethers: $[\{0-$ $\left.\left.547 \mathrm{C}_{6} \mathrm{H}_{4}\left(\mathrm{CH}_{2} \mathrm{SMe}\right)_{2}\right\} \mathrm{H}\right]\left[\mathrm{NbF}_{6}\right]$ and $\left[\left\{[9] \mathrm{aneS}_{3}\right\} \mathrm{H}\right]\left[\mathrm{NbF}_{6}\right]$. Dalton 548 Trans. 2009, 7610-7612.

549 (22) White, R. E.; Hanusa, T. P. Prediction of ${ }^{89} Y$ NMR Chemical 550 Shifts in Organometallic Complexes with Density Functional Theory. 551 Organometallics 2006, 25, 5621. 